Egypt. Acad. J. biolog. Sci., 2 (1) : 89 - 101 (2009)

E. mail.egyptianacademic@yahoo.com

ISSN: $1687-8809$

Received: $10 / 2 / 2009$

www.eajbs.eg.net

\title{
Biocidal Activity of two botanical volatile oils against the larvae of Synthesiomyia nudiseta (Wulp) (Diptera: Muscidae)
}

Abdel Fattah A. Khalaf, Karam T. Hussein and Khater K. Shoukry

Zoology Department, Faculty of Science, Zagazig University, Zagazig-44519, Egypt

\section{ABSTRACT}

The volatile oils of golden pillar, Cupressus macrocarpa and galangal, Alpinia officinarum were extracted and their constituents were identified. Alpha pinene and trans-caryophyllene were the major isolated constituents of $C$. macrocarpa oil, and 1,8 cineole and 4-terpeniol were the major compounds of $A$. officinarum oil.

The present study revealed that the botanical volatile oils used, had morphogenic effects against $S$. nudiseta stages. These include larval-pupal intermediates, pupal-adult intermediates, deformed adults with crumpled wings and/ or deformed thorax and abdomen. Also some adults couldn't emerge and remained in their puparia.

The histological effects induced by oils treatment in the body wall were represented by degeneration and detachment of hypodermis and dissolving of the exocuticle in some regions. The histopathological effects that appeared in the midgut were shrinkage in some epithelial cells and swelling of other cells.

Key word: Biocidal, Botanical, Synthesiomyia nudiseta

\section{INTRODUCTION}

The extensive use of the synthetic insecticides lead to the biological imbalance due to the destruction of beneficial species such as parasites and predators of the pests beside the destruction of pollinating insects such as honey bees. Natural products of plants and plant derivatives are alternative agent to currently use for insect control because they constitute rich sources of bioactive chemicals. They are often active against insect species. They are biodegradable to non-toxic products. Additionally, plant-derived materials are found to be highly effective against insecticide resistant insect pests (Arnason et al., 1989; Kwon et al., 1996 and Ahn et al., 1997), so that many investigators initiated a large screening efforts poisonous effects to use them as insecticides (Khmabay et al., 2002; El-Shazly and Hussien, 2004; Prowse et al., 2006 and Malarvannan and Subashini, 2007).

The main objective of the present study is to assess the toxicity, bioactivity, morphogenic and histological actions of golden pillar, Cupressus macrocarpa and galangal, Alpinia officinarum plant volatile oils against Synthesiomyia nudesita which has a significant role in transmitting the enteric bacteria to man and causing myiasis to man and many animals.

\section{MATERIAL AND METHOD}

\section{Insect culture}

Adults of Synthesiomyia nudesita were collected from some areas in Sharkia province and reared in laboratory for five successive generations before being used in experiments, according to the technique described by Busvine (1962). 


\section{Extraction and analysis technique}

Leaves of $C$. macrocapra and rhizomes of $A$. officinarum are used. The plant volatile oils were extracted by steam distillation using $300 \mathrm{~g}$ of plant in $300 \mathrm{ml}$ of water for 4-6 $\mathrm{h}$ and following the method described by Marcus and Lichtenstein (1979) and Weaver et al. (1994). The volatile oils were subjected to further analysis using GC/MS (70 ev. energy) according to the method of Likens and Nickerson (1966) and Bernharde et al. (1983). Gas chromatography/mass spectrometry (GC/MS) analysis technique was performed on Hewlett Packard gas chromatogram in National Research Centre, Cairo.

\section{Test technique}

Six different acetone concentrations of the two volatile oils were prepared in $250 \mathrm{ml}$ beaker $10 \mathrm{ml}$ of each concentration were thoroughly mixed with $100 \mathrm{gm}$ of rearing medium by using an electric blender, then acetone was evaporated. Third instar larvae of Synthesiomyia nudesita were taken from rearing media and introduced to each beaker (100 larvae). Control larvae were fed in acetone treated diet only. The percent larval mortality was recorded $24 \mathrm{hrs}$. after treatment, corrected according to Abbott (1925). Log concentration-mortality regression lines (LC.P. lines) were determined and the median lethal concentrations $\left(\mathrm{LC}_{50 \mathrm{~s}}\right)$ were estimated.

\section{Biological studies}

The effect of sublethal concentrations $\left(\mathrm{LC}_{50}\right)$ on some biological aspects of the treated stage and its subsequent developmental stages were determined. Deformed larvae, pupae and adults were also recorded.

\section{Histological studies}

Histological examinations were carried out on normal third instar larvae and those treated with sublethal concentration $\left(\mathrm{LC}_{50}\right)$ of plant oil ( $24 \mathrm{hrs}$. post treatment). Routine histological technique was used for comparisons.

\section{RESULTS AND DISCUSSION}

\section{Extractions and identification of volatile oils components}

Only 9 and $15 \mathrm{gm}$ volatile oils were extracted from one $\mathrm{kg}$ of leaves from Cupressus macrocapra and rhizomes from Alpinia officinarum by steam distillation. High resolution GC/ MS resulted in thirty volatile components in both Cupressus macrocapra and Alpinia officinarum; only thirteen and sixteen major components are identified from C. macrocarpa and A. officinarum.

Analysis of Cupressus macrocarpa essential oil showed it to be rich in alpha pinene $(67.94 \%)$, trans-caryophyllene (5.10\%), alpha cedrol (5.00\%), alpha Humulene (3.79\%), Limonene (3.69\%), and alpha Myrcene (2.98\%), (Table 1). 
Table (1): Common name and chemical structure of isolated volatile oil components of Cupressus macrocarpa

\begin{tabular}{|c|c|c|c|}
\hline Common name & $\begin{array}{l}\text { Empirical } \\
\text { formula }\end{array}$ & Structural formula & Component \% \\
\hline Pinene (alpha) & $\overline{\mathrm{C}_{10} \mathrm{H}_{16}}$ & & 67.94 \\
\hline Sabinene & $\mathrm{C}_{10} \mathrm{H}_{16}$ & & 2.94 \\
\hline Myrcene (Beta) & $\mathrm{C}_{10} \mathrm{H}_{16}$ & & 2.98 \\
\hline $\begin{array}{l}\text { Phellandrene } \\
\text { (alpha) }\end{array}$ & $\mathrm{C}_{10} \mathrm{H}_{16}$ & & 0.76 \\
\hline Limonene & $\mathrm{C}_{10} \mathrm{H}_{16}$ & & 3.69 \\
\hline $\begin{array}{l}\text { Terpinolene } \\
\text { (alpha) }\end{array}$ & $\mathrm{C}_{10} \mathrm{H}_{16}$ & & 2.05 \\
\hline 1-Bornyl acetate & $\mathrm{C}_{12} \mathrm{H}_{20} \mathrm{O}_{2}$ & & 0.89 \\
\hline Terpinenyl acetate & $\mathrm{C}_{12} \mathrm{H}_{20} \mathrm{O}_{2}$ & & 2.29 \\
\hline $\begin{array}{l}\text { Trans- } \\
\text { caryophyllene }\end{array}$ & $\mathrm{C}_{15} \mathrm{H}_{24}$ & & 5.10 \\
\hline Humulene (alpha) & $\mathrm{C}_{15} \mathrm{H}_{24}$ & & 3.79 \\
\hline Cubebene (alpha) & $\mathrm{C}_{15} \mathrm{H}_{24}$ & & 2.07 \\
\hline (+)- chamigrene & $\mathrm{C}_{15} \mathrm{H}_{24}$ & & 0.44 \\
\hline Cedrol (alpha) & $\mathrm{C}_{15} \mathrm{H}_{26} \mathrm{O}$ & & 5.00 \\
\hline
\end{tabular}


Analysis of Alpinia officinarum showed it to be rich in 1,8-cineole (72.33\%), 4-terpeniol $(3.61 \%)$, linaly propionate $(3.29 \%)$, alpha pinene $(3.11 \%)$, camphor $(2.36 \%)$ and gamma Muurlene $(2.20 \%)$, (Table 2$)$.

Table (2): Common name and chemical structure of isolated volatile oil components of Alpinia officinarum

\begin{tabular}{|c|c|c|c|}
\hline Common name & $\begin{array}{c}\begin{array}{c}\text { Empirical } \\
\text { formula }\end{array} \\
\end{array}$ & Structural formula & Component \% \\
\hline Thujene (alpha) & $\mathrm{C}_{10} \mathrm{H}_{16}$ & & 1.84 \\
\hline Camphene & $\mathrm{C}_{10} \mathrm{H}_{16}$ & & 2.06 \\
\hline Pinene (alpha) & $\mathrm{C}_{10} \mathrm{H}_{16}$ & & 3.11 \\
\hline Cineole (1.8) & $\mathrm{C}_{10} \mathrm{H}_{18} \mathrm{O}$ & & 72.33 \\
\hline Camphor & $\mathrm{C}_{10} \mathrm{H}_{16}$ & & 2.36 \\
\hline 4 Terpinol & $\mathrm{C}_{10} \mathrm{H}_{18} \mathrm{O}$ & & 3.61 \\
\hline Linalyl propionate & $\mathrm{C}_{10} \mathrm{H}_{18} \mathrm{O}$ & & 3.29 \\
\hline 4-phenyl -2- butanon & $\mathrm{C}_{10} \mathrm{H}_{12} \mathrm{O}$ & & 1.30 \\
\hline $\begin{array}{l}\text { 2-phenyl ethyl } \\
\text { butanoate }\end{array}$ & $\mathrm{C}_{12} \mathrm{H}_{16} \mathrm{O}_{2}$ & & 0.77 \\
\hline (Trans)caryophllene & $\mathrm{C}_{15} \mathrm{H}_{24}$ & & 1.82 \\
\hline Bergamotene (alpha) & $\mathrm{C}_{15} \mathrm{H}_{24}$ & & 2.00 \\
\hline Humulene (alpha) & $\mathrm{C}_{15} \mathrm{H}_{24}$ & & 0.74 \\
\hline Selinene & $\mathrm{C}_{15} \mathrm{H}_{24}$ & & 0.74 \\
\hline Farnesene & $\mathrm{C}_{15} \mathrm{H}_{24}$ & & 1.08 \\
\hline Gamma Muurolene & $\mathrm{C}_{15} \mathrm{H}_{24}$ & & 2.20 \\
\hline $\begin{array}{l}8 \text {-methoxy-2- } \\
\text { tetralone }\end{array}$ & $\mathrm{C}_{12} \mathrm{H}_{12} \mathrm{O}_{3}$ & & 1.04 \\
\hline
\end{tabular}




\section{Biological studies}

The insecticidal activity of the volatile oils of $C$. macrocarpa and $A$. officinarum was evaluated. On the basis of mortality percentages, it was found that they showed a promising insecticidal activity.

The toxicity of the volatile oils of $C$. macrocarpa and A. officinarum against the third instar larvae of $S$. nudiseta exposed for 24 hours showed that the $\mathrm{LC}_{50 \mathrm{~s}}$ are $1.11 \%$ and $2.37 \%$, respectively (Table 3 and Fig. 1 ).

The effect of oil treatment on treated larval stage and its subsequent developmental stages were recorded.

Table (3): Toxicity and the relative potency of Cupressus macrocarpa and Alpinia officinarum volatile oils against Synthesiomyia nudiseta

\begin{tabular}{|c|c|c|c|c|c|c|}
\hline \multirow{2}{*}{ Tested plants } & \multirow{2}{*}{ Conc. \% } & \multirow{2}{*}{$\begin{array}{c}\text { Mortality } \\
\% \\
\end{array}$} & \multirow{2}{*}{$\mathbf{L C}_{50}$ (confidence limits) } & \multirow{2}{*}{ Slop functions } & \multicolumn{2}{|c|}{ Relative potency based on } \\
\hline & & & & & C. macrocarpa & A. officinarum \\
\hline \multirow{6}{*}{ 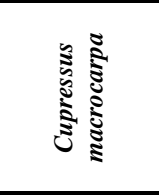 } & 0.39 & 25 & \multirow{6}{*}{$\begin{array}{c}1.11 \\
(0.891-1.374)\end{array}$} & \multirow{6}{*}{1.307} & \multirow{6}{*}{1} & \multirow{6}{*}{0.478} \\
\hline & 0.78 & 40 & & & & \\
\hline & 1.56 & 50 & & & & \\
\hline & 3.12 & 75 & & & & \\
\hline & 6.25 & 85 & & & & \\
\hline & 12.5 & 100 & & & & \\
\hline \multirow{6}{*}{ 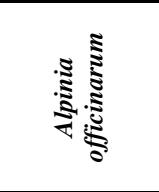 } & 0.39 & 15 & \multirow{6}{*}{$\begin{array}{c}2.37 \\
(2.05-2.72)\end{array}$} & \multirow{6}{*}{1.662} & \multirow{6}{*}{2.09} & \multirow{6}{*}{1} \\
\hline & 0.78 & 25 & & & & \\
\hline & 1.56 & 25 & & & & \\
\hline & 3.12 & 45 & & & & \\
\hline & 6.25 & 90 & & & & \\
\hline & 12.5 & 100 & & & & \\
\hline
\end{tabular}

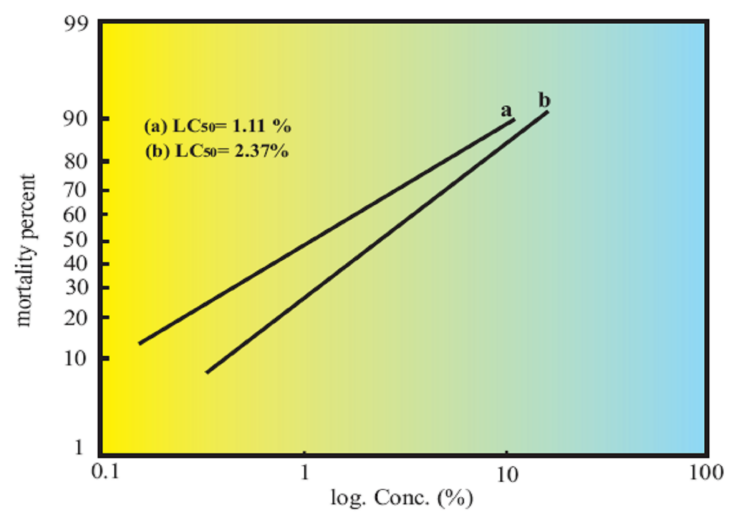

Fig. (1):Log. Conc.-Mortality regression lines of the plant volatile oils against Synthesiomyia nudiseta larvae. (a) Cupressus macrocarpa (b) Alpinia officinarum.

\section{A. Delayed effect of oils treatment on some biological activities}

The results in Table (4) illustrate that both oils treatment of the third instar larvae induced a decrease in the percentage of pupation by $91.57 \%$ and $91.34 \%$ in treatment with $C$. macrpocarpa and A. officinarum respectively.

The obtained Results in Table (4) clearly demonstrate the treated third instar larvae of $S$. nudiseta with $\mathrm{LC}_{50 \mathrm{~s}}$, sublethal concentrations of the two volatile oils reduced percentage of adult emergence by $-91.57 \%$ and $-91.34 \%$ with $C$. macrpocarpa and $A$. officinarum respectively. In treatment with the two volatile oils no oviposition observed at all. 
Table (4): Effect of larval treatment with plant volatile oils on pupation and percentage adult emergence of Synthesiomyia nudiseta.

\begin{tabular}{|l|c|c|c|c|}
\hline \multirow{2}{*}{ Treatments } & \multicolumn{2}{|c|}{ Pupal stage } & \multicolumn{2}{c|}{ Adult stage } \\
\cline { 2 - 5 } & $\begin{array}{c}\text { Pupation\% } \\
\text { (Mean } \pm \text { SE) }\end{array}$ & $\begin{array}{c}\text { Change } \\
\%\end{array}$ & $\begin{array}{c}\text { Adult emergence\% } \\
\text { (Mean } \pm \text { SE) }\end{array}$ & Change\% \\
\hline $\begin{array}{l}\text { Cupressus } \\
\text { macrocarpa }\end{array}$ & $11.80 \pm 0.80 *$ & -86.8 & $7.4 \pm 0.87 *$ & $-91.57 \%$ \\
\hline $\begin{array}{l}\text { Alpinia } \\
\text { officinarum }\end{array}$ & $13.20 \pm 1.31 *$ & -85.27 & $7.6 \pm 1.12 *$ & $-91.34 \%$ \\
\hline Control & $89.6 \pm 3.26$ & - & $87.80 \pm 2.65$ & - \\
\hline
\end{tabular}

(-) reduction from control.

* very high significant.

It is generally accepted that toxic materials of plant origin exert an inhibitory growth effect. Similar effects of some phytochemicals on some insect species have been documented by many authors. Shoukry (1996) attributed the toxicity of volatile oils of $C$. inerme leaves and $M$. chamomilla flowers on house fly, due to the presence of monoterpene, hydrocarbons, and sesquiterpene. Khalaf and Hussein (1997) declared that the toxicity of $C$. citratus and $R$. officinalis volatile oil attributed to the presence of terpenoid compounds which have different methyl and hydroxyl groups in different position. Similar results were recorded by Shoukry et al. (2002) on $P$. interpunctella, El-Domiaty et al. (2003) on M. domestica, El-Shazly and Hussein (2004), on M. domestica, Traboulsi et al. (2005) on C. pipiens and Wang-Jian et al. (2005) on M. domestica.

The percentage pupation was decreased due to larval treatment with volatile oils, simil ar effects of some botanical plant extracts have been reported by Abou ElEla et al. (1995) and Youssef (1997) on the house fly M. domestica, Nassar et al. (1997) on P. argyrostoma and Sabry (2004) on C. albecipes.

High reduction in adult emergence was achieved by larval treatment with $C$. macrocarpa and A. officinarum volatile oils. These results are in agreement with the findings of Hussein and Aioub (2000) on M. stabulans, El-Shazly and Hussein (2004) on $C$. pipiens, $M$. domestica and C. capitata larvae and Traboulsi et al. (2005) on $C$. pipiens larvae.

\section{B. Morphogenic abnormalities}

Treatment of the third larval instar of $S$. nudiseta with the tested two volatile oils decrease the survival of the larvae and gave rise to noticeable larval, pupal and adult abnormalities (Figs. 2, 3\& 4).

\section{Deformed larvae}

Some deformed larvae were pigmented and larval-pupal intermediate which had parts of pupal cuticle with persisting last larval skin in their anterior end (Fig. $2 \mathrm{~b}$ \& c).

\section{Deformed pupae}

Some of treated larvae were able to pupate, however, the resultant puparia of some individuals showed $\mathrm{C}$-shaped pupae, elongated pupae and balloon shaped pupae (Fig.3b,c\& d).

\section{Deformed adult}

From Fig ( $4 b \& c)$, most of the pupae failed to reach adults however some emerged adult have various degrees of morphological abnormalities. Some individuals showed a dominance of incomplete adult eclosion varying from complete eclosion of adults with only their legs or wings were partially attacked to the puparium. However in most cases, only the head and thorax were emerged from the puparium. Mean while 
some adult were completely free but possessed abnormal appearance such as: severely crumpled wings, deformation in the thorax and abdomen.

These results are in agreement with the data reported by Hussein (1995) on $P$. aegyptiaca after treatment with some plant extract. Abahussain (1999) studied the morphological effects induced by $C$. procera in $C$. pipiens and A. multicolor, those morphological effects were larval-pupal intermediate and pupal-adult intermediate. Hussein (2000b) on S. littoralis treated with volatile oil. El-Domiaty et al. (2003) found shrinkage of the pupae and folding of the wings of adults as a result of treatment of third instar larvae of $M$. domestica with P. nigra volatile oil. Sabry (2004) stated that, treatment of third instar of $C$. albiceps with T.vulgaris and Z. officinale produce larval pupal intermediate and adults with crumped wings. Ibrahim (2006) found larval pupal intermediate as a result of treatment of $S$. littoralis larvae with seeds extracts of E. cyclocarpum.

This indicates that volatile oil of $C$. macrocarpa and A. officinarum might act as an insect growth inhibitor, where Wright (1970) indicate that such malformation is a true juvenile hormone effect. Cruichashank and Plamere (1971) mentioned that terpenoid amides act as insect juvenile hormone, however the two volatile oils used in this study belong to terpen group in their structure and act as juvenoids or IGRs. Our results are in accordance with David et al. (1988), Singh et al. (1989) and Schearer (1984).

\section{Histopathological studies.}

\section{A. Integument:}

The structure of the normal integument of larvae of Synthesimyia nudiseta consists of the inner basement membrane, a single cell layer and outer cuticle which is differentiated into an outer epicuticle and an inner endocuticle (Fig. 5a).

Severe damage was occurred on the integument of $S$. nudiseta larvae when they were treated by volatile oils. Complete disintegration in the hypodermis of larval cuticle was observed. They elicited a lack of differentiation between exocuticle and endocuticle, destruction of the basement membrane and appearance of vacuoles between cuticle and hypodermis (Fig.5b).

Similar observations were reported with azadirachtin against the larvae of $E$. varviests. They showed degeneration in the hypodermal cells in addition to cuticular abnormalities (Schluter \& Schulz, 1983 and Schuter, 1986). Also the integument of $S$. littoralis larvae was affected, as degeneration of hypodermal cells, and irregular thickness of the cuticle when the larvae were fed on caster bean leaves treated with $A$. monosperma, Z. coccineum and L. termis extracts. Also, treatment of S. littoralis larvae with plant extracts of both $B$. tournefortii and $Z$. coccineum elicited degeneration of the cuticle and detachment of the epidermal cell from each other (Younes et al., 1999). Also, Shoukry et al. (2002b) found detachment of cuticle from hypodermis, disintegration in the hypodermis and destruction of the basement membrane when $P$. interpunctella larvae treated with certain volatile oils. Sabry (2004) estimate the similar results on $C$. albiceps.

\section{B. Muscles:}

The muscles are composed of striated fibers. Each fiber consists of a number of paralled fibrillate or sacrostyles, occupying the whole of the cross section of the fiber and are laid down in plasma or sacroplasm. The nuclei of the sacroplasm are disposed immediately beneath the sarcolemma (Wigglesworth, 1947).

The histopathological effect of volatile oils on muscles was ranged between slight degeneration by the occurrence of fissures, to complete destruction of the whole 
tissue. The appearance of fissure and the breaking down of muscles into small parts are attributed to the destruction of the sarcolemma (Fig.5b).

These results are well agreed with those obtained by Hussein (1995); Shoukry (1996); Hussein (2000b); Shoukry et al. (2002b), Sabry (2004) and Ibrahim (2006).

\section{Fat bodies:}

Histological structure of the normal fat bodies indicated that they are composed of two layers. An outer or partial layer which is formed of ribbons beneath the body wall and an inner or visceral layer surrounding the various organs. The ribbon consist of many irregular cells. Their cells surrounded by sheath (Fig.5a).

The histological changes were caused by the two volatile oils used in this study showed a noticeable destruction on the fat body cells, as vacuolization of the fat cells, destruction of the membranous sheath (Fig.5b).

\section{Midgut:}

Cross section in the normal midgut shows one layer of epithelial cells resting on the basement membrane, muscular layer consisting of inner circular muscle, and outer scattered groups of longitudinal muscles (Fig.6a).

Volatile oil treatment induced severe effect on the mid-gut, where they are regarded shrinkage in some epithelial cells and swelling of other cells presumably due secretory activities. The boundaries of epithelial cells were extensively damaged, showed a great destruction of muscular cells, necrotic epithelium and detachment of the basement membrane (Fig.6b).

These results are in agreement with findings of Emara and Assar (2001), Shoukry et al. (2002), Sabry (2004) and Ibrahim (2006).

\section{E. Salivary gland:}

The wall of normal salivary gland consists of a small number of large cells, which have large nuclei (Fig.7a). Signs of necrosis and degeneration in the nuclei and cytoplasm of the salivary gland cells are regarded as a rupture of the cells membrane of the salivary gland with volatile oil treatment (Fig.7b).

\section{REFERENCES}

Abahussain, M.O. (1999). The effect of Calotropis Procera (AIT) (Asclepiadacea) on Culex pipiens and Anopheles multicolor (Diptera: Culicidae). J. Egypt. Ger. Soc. Zool. 30: 205-214.

Abbott, W.S. (1925). A Method of computing the effectiveness of insecticide. J. Econ. Entomol., 18: 265-267.

Abou El Ela, R.G.; Helmy, N.M.; El-Monairy, O.M. and Salah, H. (1995). Biological activity of an extract from Hyoscyamus muticus on Musca domestica (Diptera: Muscidae). Bull. Ent. Soc. Egypt. Econ. Ser., 22: 27- 35.

Ahn, Y.J.; Kwon, M.; Park, H.M. and Han, C.G. (1997). Potent insecticidal activity of Ginkgo biloba-derived trilactone terpenes against Nilaparvata lugens. In phytochemical pest control Agents; Hedin, P. Hollingworth, R., Miyamoto, J., Masler, E., Thompson, D., Eds.; Acs Symposium series 658; American Chemical society: Washington, DC., pp. 90- 105.

Aranson, J.T.; Philogne, B.J.R. and Morand, P. (1989). Insecticides of plant origin; ACS symposium series 387; Amer. Chem. Soc., Washington, DC, pp.164-172.

Bernhard, R.A.; Shibamoto, T.; Yamaguchi, K. and White, E. (1983). The volatile constituents of Schinus molle. L. J. Agric. Food. Chem., 31: 463- 466.

Busvine, J.R. (1962). A laboratory technique for meansuring the susceptibility of house flies and blow flies to insecticides. Lab. Port., 11: 464-465. 
Cruickashank, P. A. and Palmere R. M. (1971). Terpenoid amides as insect juvenile hormones. Nature, 233: 488-489.

David, B.V.; Sukumaran, D. and Kandasamy, C. (1988). The Indian Privet Vitex Negundo Linn. Aplant possessing promising Pesticidal activity. Pesticides. Rev. of Appl. Entomol. Series "A", 22(2): 27-30.

El-Domiaty, M.M.; El-Shafae, M.M.; Abdel-Aal, M.M. and Rashad, E.M. (2003). Chemical composition and insecticidal activity of Populus nigra buds; growing in Egypt. J. Egypt. Acad. Soc. Environ. Develop., 3(2): 21-40.

El-Shazly, A.M. and Hussein, K.T. (2004). Chemical analysis and biological activities of the essential oil of Teucrium leucocladum Boiss. (Lamiaceae). Biochem. Syst. and Ecology, 32(7): 665-674.

Emara, T.E. and Assar, A.A. (2001). Biological and histopathological activity of some plant extracts against the cotton leaf worm, Spodoptera littoralis (Lepidoptera: Noctuidae). J. Egypt. Ger. Soc. Zool., 35: 1-15.

Hussein, K.T. (1995). Effect of some plant extracts in the control of a non-biting Muscoid fly. Ph. D. Thesis, Fac. Sci. Zag. Univ., Egypt.

Hussein, K.T. (2000b). Toxicity and some aspects of the action IGR's and botanical essential oils on the cotton leaf worm, Spodoptera littoralis (Boisd) (Lepidoptera: Noctuidae). J. Egypt. Ger. Soc. Zool., 33: 81-91.

Hussein, K.T. and Aioub, A.A.A. (2000). Toxicity and potency of some botanical extracts with certain insecticides in the control of Muscina stabulans (FALLEN) (Diptera-Muscidae). J. Egypt. Ger. Soc. Zool, 33: 111-120.

Ibrahim, A. A. (2006). Toxicological studies on an insect of lepidopterous pests. M.Sc. Thesis, Fac. Sci. Zag. Univ. Egypt.

Khalaf, A.A. and Hussein, K.T. (1997). Biocidal activity of selected volatile oils of plant origin against Muscina Stabulans (FALLEN) (Diptera-Muscidae). Ain Shams Sci. Bull., 35: 307-329.

Khambay, B.P.S.; Beddie, D.G. and Simmands, M.S.J. (2002). An insecticidal mixture of tetramethyl cyclohexenedione isomers from Kunzea ambigua and Kunzea baxterii. Phytochemistry. 59(1): 69-71.

Kwon, M.; Ahn, Y.J.; Yoo, J.K and Choi, B.R. (1996). Potent insecticidal activity of extracts from Ginkgo biloba leaves against Nilaparvata lugens (Homoptera: Delphacidae). Appl. Entomol., Zool., 31L 162- 166.

Likenes, S.T. and Nickerson, G.B. (1966). Isolation and identification of volatiles. J. Chromatogr., 21: 1-8.

Malarvannan, S. and Subashini, H.D. (2007). Effect of Dodonaea angustifolia crude extract on biochemical profile of Helicoverpa armigera (Hubner) (Noctuidae: Lepidoptera), Biochem. and Cellular Archives; 7 (1): 1-8.

Marcus, C. and P. Lichtenstein, (1979). Biologically active components of anise toxicity and interaction with insecticides in insects. J. Agric. Food Chemi, 27: 1217-1223.

Nassar, M.I.; Kandil, O.M. and Hassanain, M.A. (1997). The potentiality of Sorghum bicolor and Nerium oleander extracts in the control of the grey flesh fly, Parasarcophaga argyrostoma (Diptera: Sarcophagidae). J. Egypt. Ger. Soc. Zool., 22: 235- 251.

Prowse, G.M.; Galloway, T.S.; Foggo, A. (2006). Insecticidal activity of garlic juice in two dipteran pests. Agric. Forest. Entomol., 8(1): 1-6.

Sabry, H.M. (2004). The use of some biological control agents against amyiasis producing fly. M.Sc. Thesis, fac. Sci. Zag. Univ. Egypt. 
Schearer, W.R. (1984). Components of oil of tansy (Tanacetum Vulgare) that repel Colorado potato beetles (Leptinotarsa decemlineata) J. Nat. Prod., 47: 964969.

Schluter, U. (1986). Effects of azadirachtin on developing tissues of various insect larvae. Proc. $3^{\text {rd }}$ Int.Neem Conf., 331-348.

Schluter, U. and Schulz, W.D. (1983). Strucrural damage caused by neem in Epilachna varivestis: A summary of histological and ultrastructural data. I. Tissues affected in larvae. Proc. $2^{\text {nd }}$ Neem Int. Conf., 227-236.

Shoukry, I.F. (1996). Morphogenic and histopathological effects induced by two natural volatile oils in the house fly, Musca domestica L. (Diptera: Muscidae). Proc. Fir. Conf. On the role of science in the development of Egyptian society and Environ. Zagazig Univ. Benha branch, Egypt. 21- 23 Oct.

Shoukry, I.F.; Khalaf, A.A.; Hussein, K.T. and Khater, K.S. (2002). Assessment and characterization of volatile oil treatments on the Indian meal moth, Plodia interpunctella HB. (Lepidoptera: Pyralidae). Ain Shams Science Bull., 40: 115-135.

Singh, D.; Siddiqui, M.S. and Sharma, S. (1989). Reproductive retardant and fumigant properties in essential oils against rice weevil (Coleoptera: Curculionidae) in stored wheat. J.Econ. Entomol., 82 (3): 227-233.

Traboulsi, A.F.; El-Haj, S.; Tueni, M.; Taoubi, K.; Nader, N.A. and Mrad, A. (2005). Repellency and toxicity of aromatic plant extracts against the mosquito Culex pipiens molestus (Diptera: Culicidae). Pest Manag. Sci, 61(6): 597-604.

Wang-Jian; Li-ya and Lei Chaoliang (2005). The repellency and fumigant activity of Artemisia vulgaris essential oil to Musca Domestica Vicina. Chinese. Bull. Entomol., 42(1): 51-53.

Weaver, D.K.; Wells, C.D.; Dunkel, F.V.; Bertsch, W.; Sing, S.E. and Sriharan, S. (1994). Insecticidal activity of floral, foliar and root extracts of Tagetes minuta (Asteraceae) against Mexican bean weevils (coleopteran: Bruchidae). J. Econ. Entomol., 87(6): 1718-1725.

Wigglesworth, V.B. (1947). The principles of insect physiology (Metheurn, London, 434 Pages).

Wright, J.E. (1970). Hormone for control of livestock arthropods. Juivenile hormone activity in the stable fly. J. Econ. Entomol., 63: 878-883

Younes, N.W.F.; Abul- Dahab, F.F; Assar, A.A and Hanna, M.M (1999). Histopathological studies on the effect of some botanical extracts on the cotton leaf worm, Spodoptera littoralis (Boisd.) (Lepidoptera: Noctuidae) II- effects of the integument, the mid gut and fat body. $2^{\text {nd }}$ Sci. Conf. On the role of science in the development of Egyptian society and Environment, Zagazig Univ., Fac. Sci, Benha, 113- 129,

Youssef, N.S. (1997). Toxic and synergistic properties of several volatile oils against larvae of the house fly, Musca domestica vicina maquart (Diptera: Muscidae) J. Egypt. Ger. Soc. Zool., 22: 131- 149. 


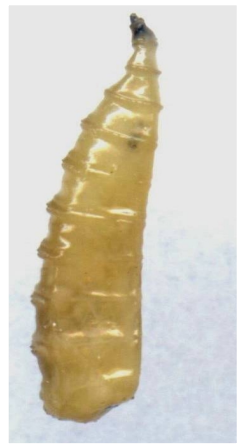

(a)

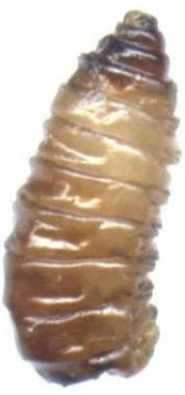

(b)

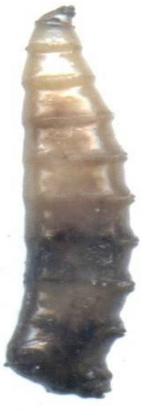

(c)

Fig (2): Normal and deformed larvae of Synthesiomyia nudiseta treated with volatile oils. a) Normal larvae. b) Larval pupal intermediate. c) Larvae with darkened cuticle.

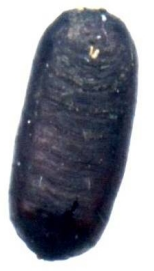

(a)

(b)

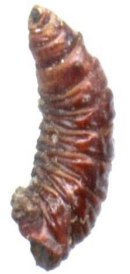

(c)
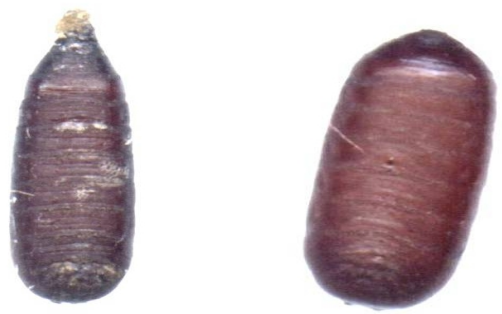

(d)

Fig. (3): Normal and deformed pupae of Synthesiomyia nudiseta treated with volatile oils.

a) Normal pupae.

c) Elongated pupae.

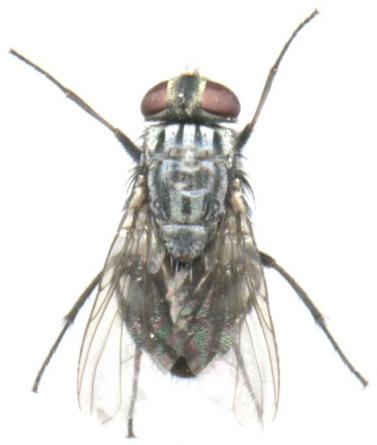

(a)

b) C-Shaped pupae.

d) Balloon Shaped pupae.

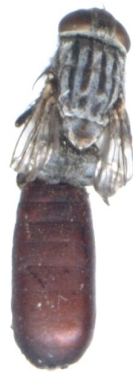

(b)

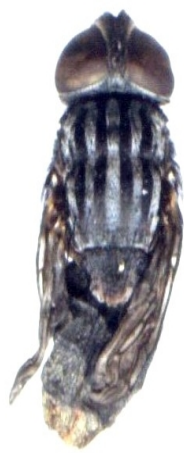

(c)

Fig. (4): Normal \& deformed adults of Synthesiomyia nudesita treated with volatile oils.

a) Normal adult ( + ). b) Incomplete adult eclosion. c) Adult with crumpled wings. 

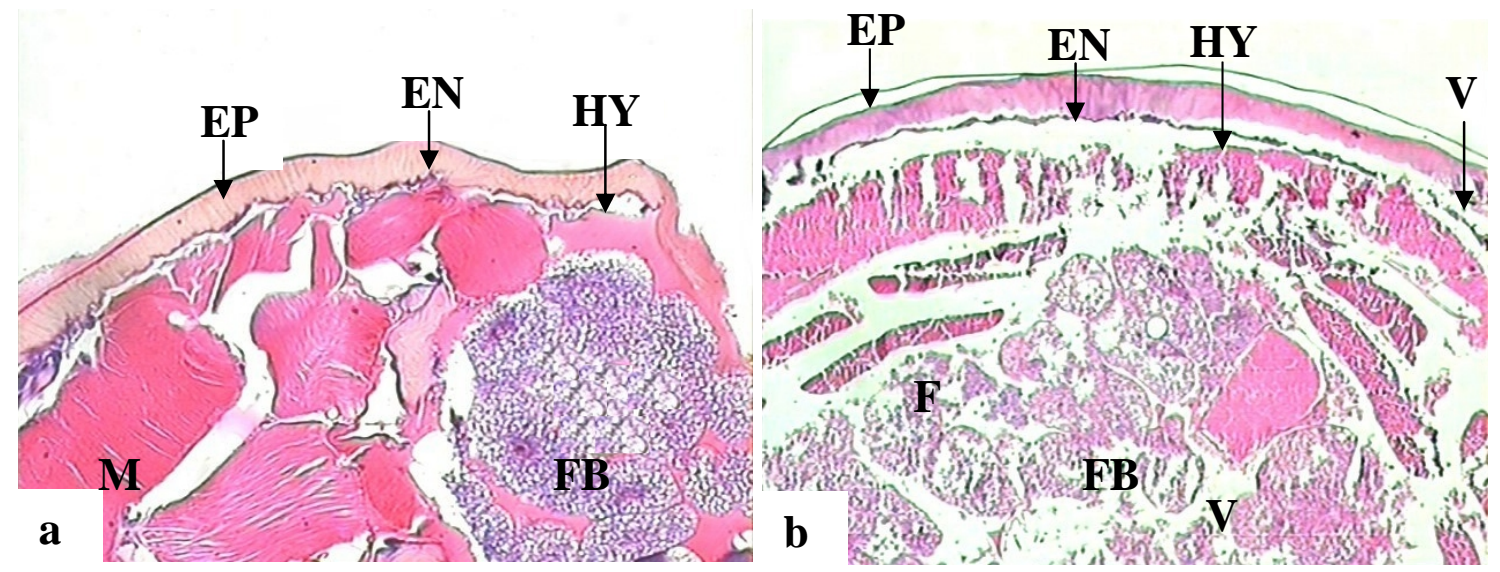

Fig. (5): Photomicrographs of T-S in the cuticle, muscles and fat bodies of untreated and plant volatile oil treated Synthesiomyia nudiseta larvae, $(X=200)$. a- Untreated b- Treated

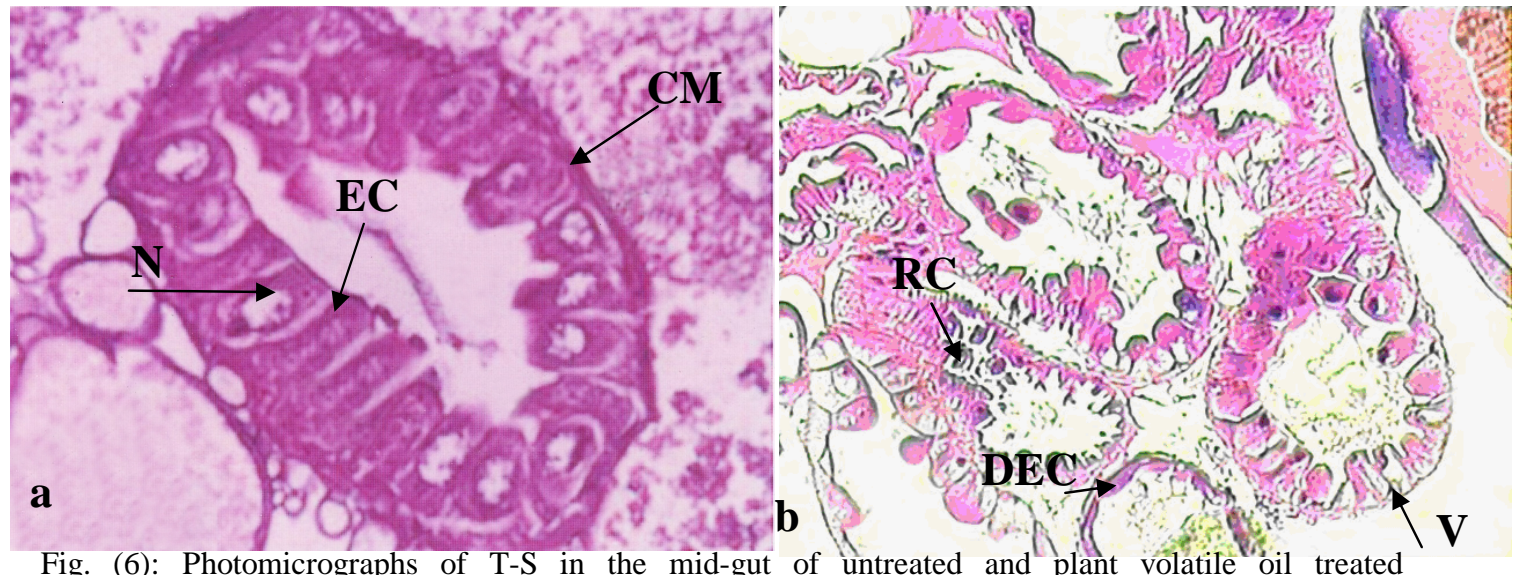

Fig. (6): Photomicrographs of $\mathrm{T}-\mathrm{S}$ in the mid-gut of untreated and plant volatile oil treated Synthesiomyia nudiseta larvae, $(X=200)$.

a- Untreated b-Treated

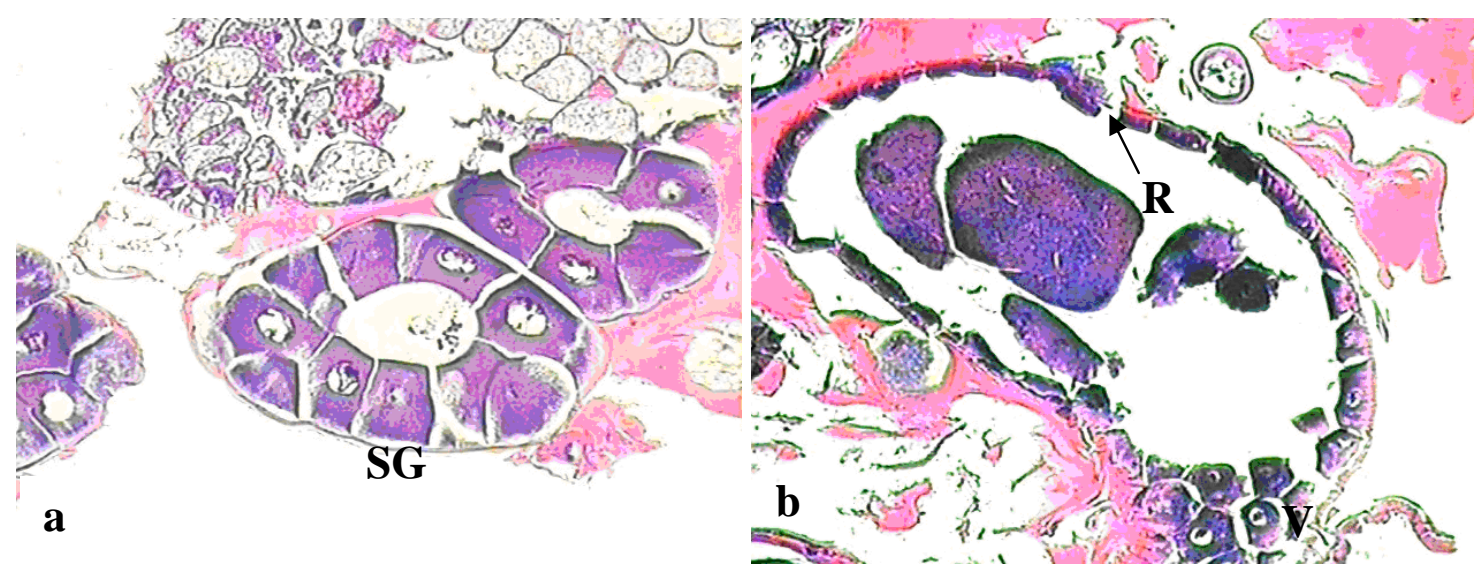

Fig. (7): Photomicrographs of T-S in the salivary gland of untreated and plant volatile oil treated Synthesiomyia nudiseta larvae, $(X=200)$
a- Untreated
b- Treated

EN: Endocuticle EP: Epicuticle F: Fissures FB: Fat Bodies HY: Hypodermis M: Muscles V: Vacuoles R: Rapture SG: Salivary gland CM: Circular muscles DEC: Degenerated epithelial cells EC: Epithelial cells N: Nucleus RC: Ruptured cells 


\section{ARABIC SUMMARY}

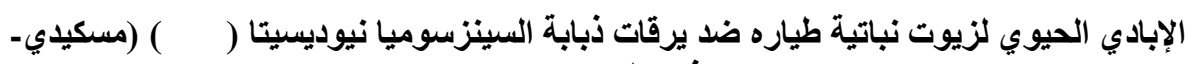

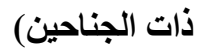

عبد الفتاح عبد المجيد أحمد خلف- كرم طلب حسين- كريمة شكرى خاطر قسم علم الحيوان - كلية العلوم - جامعة الزقازيق

استخدم التقطير البخـاري لاستخلاص الزيوت النباتيـة الطياره من نباتي السرو الليموني والجالنجال النيال

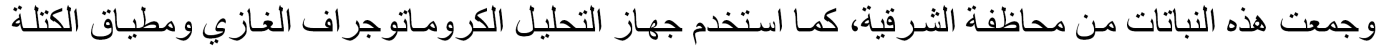

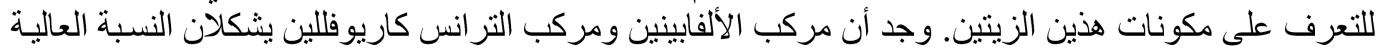

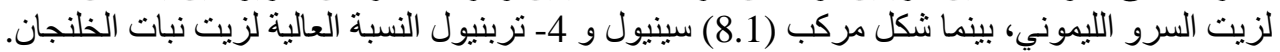

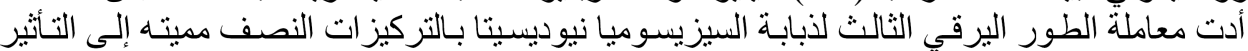

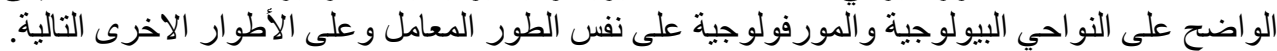

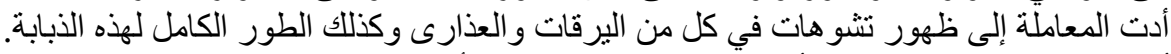

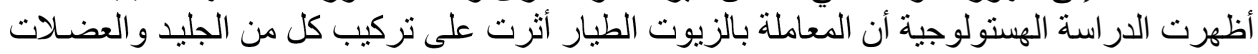

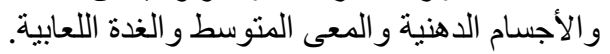

وفي النهاية نوصي بإستخدام هذين الزيتين كوسيلة آمنة في مقاومة هذه الحشرة الضارة. 